\title{
Comparative Analysis of Some Trace Element Contents of Staple Cereals Grown in Plateau State, North-central Nigeria
}

\author{
Kiri Hashimu Jaryum ${ }^{1,}$, , Samuel Yusufu Gazuwa ${ }^{1}$, Olukemi Dayok ${ }^{2}$, Justina Ononye Onyeka ${ }^{1}$ \\ ${ }^{1}$ Department of Biochemistry, College of Medical Sciences, University of Jos, Jos, Nigeria \\ ${ }^{2}$ Department of Science Laboratory Technology, Plateau State Polytechnic, Barkin Ladi, Nigeria
}

Email address:

jaryumkh@gmail.com (K. H. Jaryum)

${ }^{*}$ Corresponding author

\section{To cite this article:}

Kiri Hashimu Jaryum, Samuel Yusufu Gazuwa, Olukemi Dayok, Justina Ononye Onyeka. Comparative Analysis of Some Trace Element Contents of Staple Cereals Grown in Plateau State, North-central Nigeria. International Journal of Nutrition and Food Sciences. Vol. 5, No. 2, 2016, pp. 129-133. doi: 10.11648/j.ijnfs.20160502.16

Received: February 29, 2016; Accepted: March 11, 2016; Published: March 24, 2016

\begin{abstract}
Cereals account for more than half of the staple foods of the population in sub-Saharan Africa and Asia. Elemental composition of foodstuffs varies according to genetic and environmental factors, with environment playing a greater role for the crop type. In this study, four trace elements were determined in four staple cereal foodstuffs consumed in North-Central Nigeria with a view to comparing them. The cereals studied were Oryza sativa (rice), Zea mays (maize), Sorghum bicolor (guinea corn) and Eleusine coracana (finger millet). Mineral concentrations were determined by atomic absorption spectrophotometry method. Data obtained were statistically analysed by the Student's t-test. Guinea corn has the highest elemental composition with zinc been the most abundant of the elements, occurring at $0.3690 \pm 0.0007 \mathrm{mg} / 100 \mathrm{~g}$; followed by millet with Fe occurring at $0.2740 \pm 0.0004 \mathrm{mg} / 100 \mathrm{~g}$. Copper was the least abundant trace element found in the cereals; occurring at $0.0006 \pm 0.0002 \mathrm{mg} / 100 \mathrm{~g}$ in millet, followed by $0.0012 \pm 0.0001 \mathrm{mg} / 100 \mathrm{~g}$ in rice. Moreover, it was discovered that the levels of trace elements in all the cereals (except $\mathrm{Zn}$ in guinea corn) studied were lower than the FAO/WHO dietary requirements; the estimated average requirement, EAR; and also the recommended daily allowance, RDA. It was concluded that the studied population might be at risk of deficiencies of these elements.
\end{abstract}

Keywords: Nutritional Deficiencies, Cereals, Copper, Zinc, Rural Areas

\section{Introduction}

The most important crop species which supply the majority of the world population's nutritional needs are the graminaceous cereals such as rice, maize, wheat, barley, and sorghum $[1,2]$. Cereals, generally, are a source of food for a large portion of the world's population; providing the populace with carbohydrates, proteins, fats and dietary fibre, as well as vitamins and mineral elements. In developing countries, cereals account for more than half of the population's staple food [3]. In developed countries like the USA, approximately $40 \%$ of cereals, especially maize, is used for ethanol production [4]. Like any food crop, the elemental content of cereals varies widely. This is so because more than the genetic factor, the environmental conditions prevailing in the growing region affect the mineral content of these food grains [5]. It should be noted that in developing countries cereals are generally the main source of dietary mineral intake. Furthermore, with respect to crop mineral contents, it is important to note that, according to some studies, problems of mineral deficiency have been aggravated in the process of the green revolution [5], and several studies report lower levels of micronutrients, including zinc, in modern varieties of rice and wheat in comparison with traditional varieties $[6,7,8,9]$. Also, flooding of soils as practiced with irrigated rice production may cause deficiencies in micronutrients $[10,11,12]$.

While higher yields are of direct benefit to farmers, higher mineral contents of crops have the potential to contribute to a reduction in the occurrence of mineral deficiency in humans. For some countries or regions there are clear indications of a direct relationship between low soil mineral contents and the occurrence of deficiency. For example, a study on Bangladesh 
reports a direct link between soil zinc contents, zinc contents of crops (rice), and human zinc deficiency [13]. Minerals such as $\mathrm{Fe}$ and $\mathrm{Zn}$ are found in low amounts in cereal- and tuber-based diets - and the bioavailability of non-hem Fe is low. Therefore, it is not possible to meet the recommended levels of $\mathrm{Fe}$ in the staple-based diets through a food-based approach unless some meat or fish is included [4]. Globally, Fe deficiency has grown from about $30 \%$ in the 1960 s to over $40 \%$ in the mid-1990s [14]. Currently, it is estimated that over $60 \%$ of the world's six billion people are Fe deficient and over $30 \%$ are $\mathrm{Zn}$ deficient. In addition, $\mathrm{Cu}$ deficiency occurs in many developed and developing countries [15]. Six trace elements are needed for plant growth - boron, copper, iron, manganese, molybdenum and zinc. A further three - cobalt, selenium and iodine are also needed to control animal health problem. They are de facto among the most important factors in maintaining and recovering health; suggesting that deficiency in one can cause serious health hazard. Trace elements function as cofactors to enzymes and metabolic proteins, structural components of other proteins and hormones. Insufficient intake of trace elements can cause symptoms of nutritional deficiency. The aim of this research is to analyze and compare the differences in composition of mineral element contents of some cereal foodstuffs grown in North-Central Nigeria with a view to contributing to the knowledge of the extent of variability of trace elements in local staple foodstuffs, and hence the proper consumption based on needs.

\section{Materials and Methods}

\subsection{Reagents}

High purity nitric acid was obtained from the British Drug House, Poole, England; and perchloric acid from Sigma Aldrich Labochemikalien, German; were used as stock solutions.

A standard digestion mixture containing nitric acid and perchloric acid in the ratio $6: 1$ by volume was prepared from the stock solutions [16]. Samples were digested preparatory to the spectrophotometric analysis.

\subsection{Sample Collection}

Dried healthy samples were harvested on farmlands in various parts of Plateau State in the months of October to December, 2013, as follows: rice from Shendam; finger millet and guinea corn, from Kanam; while maize was from Mangu Local Government Areas all in Plateau State, North-Central Nigeria. Each sample was thrashed or de-husked to obtain the seed kernel, and then taken in polythene bags.

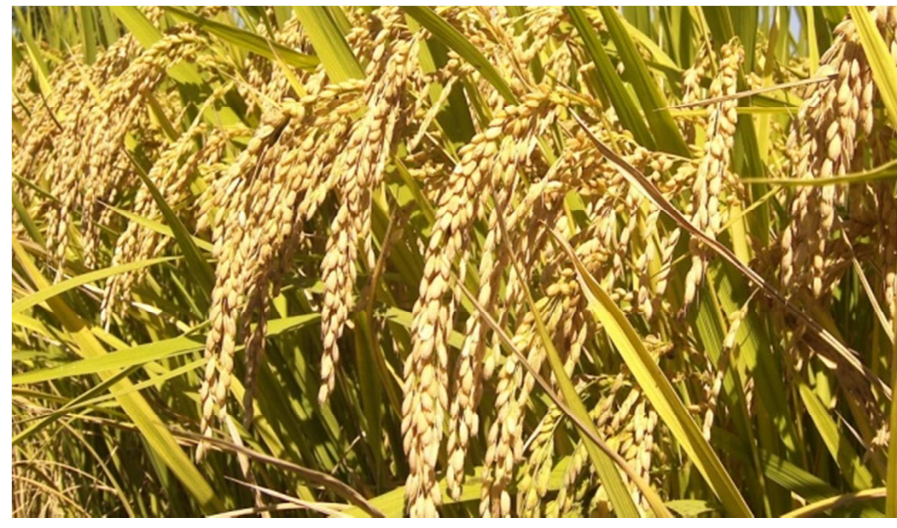

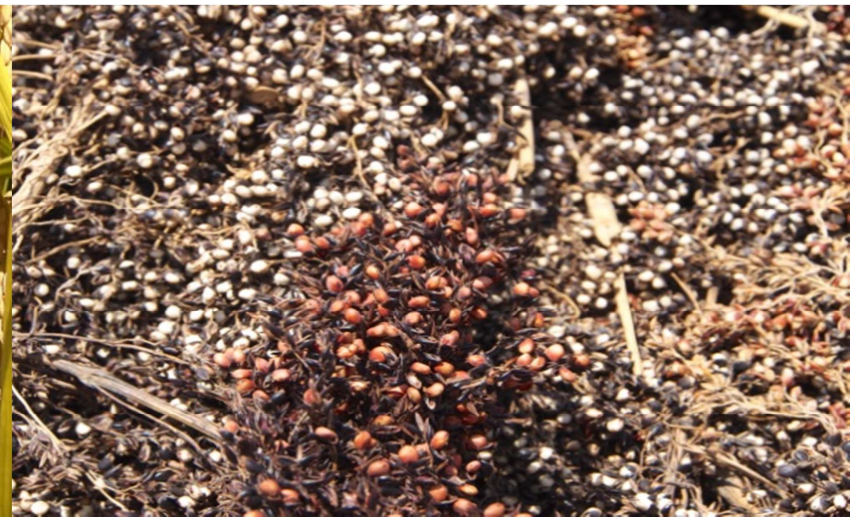

b.

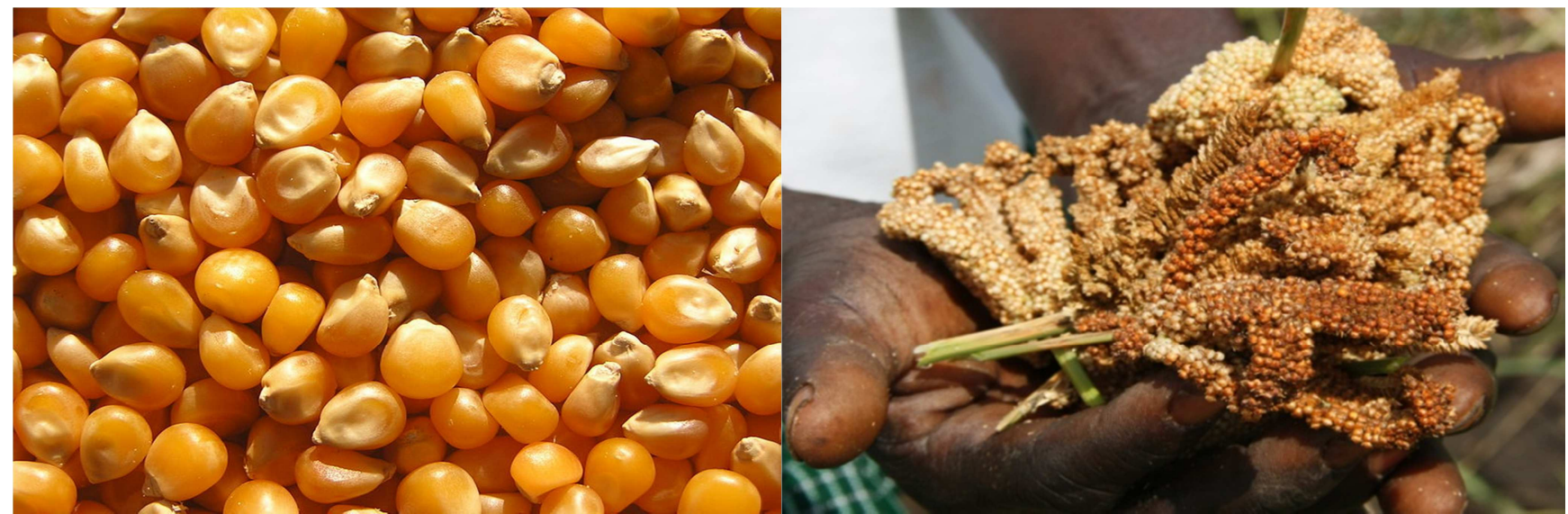

c.

d.

Figure 1. The cereal samples: (a) Rice-Oryza sativa (b) Red/white Guinea corn - Sorghum bicolor (c) Seeds of Maize - Zea mays (d) Finger Millet-Eleusine coracana. 


\subsection{Digestion Procedure and Elemental Analysis of Samples}

The seeds were then ground using Agate mortar into fine powder (particle size $\approx 300 \mu \mathrm{m}$ ). ) 0.2 grammes of the powdered samples were each taken in a crucible and ashed in a muffled furnace at $6000^{\circ} \mathrm{C}$. These were allowed to cool at room temperature and then transferred into digestion flasks. One $\mathrm{ml}$ of $\mathrm{H}_{2} \mathrm{SO}_{4}$ and $6 \mathrm{ml}$ of the digestion mixture were added and digested in a fume cupboard until white ash was obtained for each. The white ash samples obtained were dissolved in $100 \mathrm{ml}$ of de-ionized water, and the resultant solution prepared for AAS analysis.

Atomic absorption spectrometry (AAS), was conducted at Physical and Chemical Laboratories of the Nigeria Mining Cooperation (NMC), Jos, Nigeria, for quantitative determination of the mineral elements, on UNICAM 969, Shimadzu Instrument ${ }^{\mathbb{}}$, (Shimadzu Corporation, Chiyoda-ku,
Tokyo, Japan), was used for the analysis of the trace elements zinc, copper, iron, and manganese.

\subsection{Statistical Analyses}

Statistical analysis was performed using the computer software, SPSS Version 17.0 (SPSS Inc., Chicago). The statistical programme was SPSS Statistics Data Editor. The trace element contents of the grains were analysed using the Student's $\mathrm{t}$ - test. Results are expressed as arithmetic means \pm standard deviation (SD).

\section{Results and Discussion}

The result of analysis of trace element content cereals grown on farmlands in the various parts of Plateau State, Nigeria is presented on Tables 1. From the table, there is, for each crop, a wide variation in trace element contents.

Table 1. Trace element contents of cereals grown in various parts of Plateau, Nigeria.

\begin{tabular}{lllll}
\hline & & Element $(\mathbf{m g} / \mathbf{1 0 0 g})$ & & Mn \\
\hline Grain & Zn & Fe & Cu & $0.0243 \pm 0.0015$ \\
Rice & $0.0074 \pm 0.0006$ & $0.0107 \pm 0.0007$ & $0.0012 \pm 0.0001$ & $0.1083 \pm 0.0004$ \\
Maize & $0.0192 \pm 0.0006$ & $0.1290 \pm 0.0007$ & $0.0023 \pm 0.0005$ & $0.3230 \pm 0.0005$ \\
Guinea Corn & $0.3690 \pm 0.0007$ & $0.1710 \pm 0.0006$ & $0.0044 \pm 0.0002$ & $0.2100 \pm 0.0002$ \\
Millet & $0.0047 \pm 0.0004$ & $0.2740 \pm 0.0004$ & $0.0006 \pm 0.0002$ & \\
\hline
\end{tabular}

Tabulated values are means \pm SD of 3 determinations

An important component of seed quality is its chemical composition, including the concentration of micronutrients such as $\mathrm{Fe}, \mathrm{Zn}$, and $\mathrm{Cu}$ [17]. Plants face major variations in transition metals, and also concentrations of $\mathrm{Fe}, \mathrm{Zn}, \mathrm{Cu}$, and $\mathrm{Mn}$ within the rhizosphere [18]. The propensity for plants to accumulate and translocate these essential elements to edible and harvested parts depends to a large extent on soil and climatic factors, plant genotype, and agronomic management [19].

In terms of highest trace mineral level detected guinea corn has the highest followed by millet; while rice has the lowest mineral contents followed by maize. Therefore, guinea corn appears to be the richest source of dietary mineral elements among the staple grains of the area studied followed by millet, while rice and maize are the poorest, in that order. For the individual elements, iron is the most abundant, $0.3690 \pm 0.0007$ $\mathrm{mg} / 100 \mathrm{~g}$; while copper is the least, $0.0006 \pm 0.0002 \mathrm{mg} / 100 \mathrm{~g}$. Our results are in close agreement with those of Heinemann $e t$ al. [20] and Nuss and Tanumihardjo [21] who found $\mathrm{Cu}$ content in rice to be $0.18 \mathrm{mg} / 100 \mathrm{~g}$ and $0.11 \mathrm{mg} / 100 \mathrm{~g}$ respectively. Considerable genotypic differences in the concentrations of $\mathrm{Zn}, \mathrm{Fe}, \mathrm{Cu}$, and $\mathrm{Mn}$ in polished rice grains have been found, with the differences being as high as 10 -fold for $\mathrm{Zn}$ and sevenfold for $\mathrm{Fe}$ [22]. In terms $\mathrm{Fe}$ content, Gregorio et al. [23] found rice to be the least of all cereals, often containing only 0.5 or $0.6 \mathrm{mg}$ of Fe per $100 \mathrm{~g}$ after milling.

Quantitative data on trace element contents of food crops grown on different soils are limited. Nube and Voortman [24] reported that the focus in agricultural research has been more on yields, and consequently there is much literature on the relationships between micronutrient availability in soils and associated yields, but little information on crop micronutrient concentration in the edible parts of crops. Reports on trace minerals levels in Nigerian foods are very limited. Consequently, there are also limited data for the contents of trace minerals in foods. Therefore, the International Institute of Tropical Agriculture, IITA, conducted a survey between 2001 - 2003 (Maziya-Dixon et al., [25], to create awareness on the micronutrient deficiencies in Nigeria with emphasis on the trace elements zinc, iron and iodine, and the vitamins, A, D among others. International food composition tables, such as that of the United states Department of Agriculture, USDA, [26], provides a comprehensive database for trace elements and vitamins. But mineral contents of foods differ by region and the rate of mineral utilization is different according to ethnic eating pattern. Hence, one cannot rely on foreign data to evaluate mineral contents of local foods.

A similar research on legumes conducted by Jaryum et al. [27], showed higher trace mineral contents than those reported here for cereals. In an earlier research [28], similar copper content was found in cereals to be $1.23 \mu \mathrm{g} / \mathrm{g}$ in yellow maize, to as much as $5.10 \mu \mathrm{g} / \mathrm{g}$ in millet. Kanatti et al. [29] reported a pattern of variation in $\mathrm{Zn}$ and Fe concentrations in pearl millet, and attributed this variability relative to those due to genetic differences among the hybrids. The $\mathrm{Zn}$ density among the hybrids varied from 2.58 to $4.82 \mathrm{mg} / 100 \mathrm{~g}$. In terms of the recommended daily requirements, only guinea corn can be said to meet the RDAs of zinc and manganese (assuming a 
minimum daily consumption of $250 \mathrm{~g}$ ).

Mineral contents of crops is known to be related directly to the minerals in the soil on which they are grown [30,31], and Rengel et al. [30] showed that increasing mineral in nutrient solutions can result in increased mineral concentrations in grains by a factor ten or even more. Bioaccumulation of minerals is, of course, a normal and essential process enabling the organism to have reserve for latter use for metalloproteins or cofactors or protect themselves against toxic effects [32]. Furthermore, high levels of phosphate in soils can strongly reduce the availability of zinc and other elements with similar chemical properties [33]. Hence, the large variations in trace elements contents of foods reported here.

Table 2. FAO/WHO dietary recommendation of some of the minerals $(m g / \text { day })^{*}$.

\begin{tabular}{lllll}
\hline \multicolumn{5}{c}{ Population groups } \\
\hline Metal & Infants & Pregnant women & $\begin{array}{l}\text { Lactating } \\
\text { women }\end{array}$ & $\begin{array}{l}\text { Elderly } \\
(>65 y r s)\end{array}$ \\
\hline $\mathrm{Zn}$ & $2.8-4.1$ & $5.5-10.0$ & $7.2-9.5$ & $4.9-7.0$ \\
$\mathrm{Fe}$ & $8-9$ & 1040 & 15 & $11-14$ \\
$\mathrm{Cu} \dagger$ & $0.2-0.3$ & 1.0 & 1.3 & 0.9 \\
$\mathrm{Mn} \dagger$ & $0.003-0.6$ & 2.0 & 2.6 & $1.8-2.3$ \\
$\mathrm{Mg}$ & $26-36$ & 220 & 270 & $190-230$ \\
\hline
\end{tabular}

* FAO/WHO [34]

$\uparrow$ Food and Nutrition Board, 2001[35]

Merchant [36] reported that the concentration of individual trace metals in plant tissues varies over several orders of magnitude, with Fe being the most prevalent $\left(\sim 100 \mathrm{mg} \mathrm{g}^{-1}\right)$ and Mo being the least abundant.

People deficient in trace minerals are being found increasingly, with the deficiency diseases most prevalent in sub-Saharan Africa and South Asia [37]. In this vein, Klevay [38] reported that recognition of deficiency in the general population still seems rare enough to be published, but common enough that some clinics report several cases. Prevention of deficiency can have a better impact on the populace with regard to health, education, and productivity, relative to other options like supplementation [37, 39].

\section{Conclusion}

Wide variation exists in the mineral composition of the cereals analysed in this study. It is clear that diets of the studied area are often inadequate in most of the trace minerals analysed here. Assuming an average daily consumption of $250 \mathrm{~g}$, each of the foodstuffs analysed can hardly provide the populace with RDAs for the trace mineral concern. Many people in this area would not achieve the estimated average requirement, EAR, or the recommended daily allowance, RDA, for most of the trace minerals. Deficiency of trace elements in the diet, leads serious health-related human diseases. Therefore, the desirable trace element concentration in major staple foods, such as cereal grains, is an important issue and a matter of concern in agriculture and food science. Owing to the paucity of data on the trace mineral contents of staple foodstuffs in Nigeria, this research could corroborate others in contributing to the trace mineral database in Nigeria.

\section{Acknowledgement}

The authors are grateful to the Department of Biochemistry, University of Jos, for the conduct of this research.

\section{Authors' Contributions}

KHJ designed the study. JOO collected the samples, conducted the laboratory analysis, performed the statistical analysis, wrote the protocol, and wrote the first draft of the manuscript. SYG and OD managed the analyses of the study. KHJ managed the literature searches. All authors read and approved the final manuscript.

\section{References}

[1] Alloway, B. J. (2009). Soil factors associated with $\mathrm{Zn}$ deficiency in crops and humans. Environ. Geochem. Health 31:535-548. doi: 10.1007/s10653-009-9255-4.

[2] Teklic, T., Loncaric, Z., Kovacevic, V. and Singh, B. R. (2013). Metallic trace elements in cereal grain - a review: how much metal do we eat? Food and Energy Security published by John Wiley \& Sons Ltd. and the Association of Applied Biologists. DOI: $10.1002 / \mathrm{fes} 3.24$.

[3] Reynolds M., Bonnett D., Chapman S. C., Furbank R. T., Manes Y., Mather D.E., Parry M.A.J. (2011). Raising yield potential of wheat. I. Overview of a consortium approach and breeding strategies. J. Exp. Bot. 62:439-452.

[4] FAO (2012). Crop prospects and food situation. 4:40. Available at http://www.fao.org/giews/english/cpfs/index.htm (accessed February 20, 2013).

[5] Dar, W. D. (2004). Macro-benefits from micronutrients for grey to green revolution in agriculture, IFA International Symposium on Micronutrients, 23-25 February 2004, New Delhi, India.

[6] Buerkert, A., Moser, M., Kumar, A. K., Fürst, P., Becker, K. (2001). Variation in grain quality of pearl millet from Sahelian West Africa, Field Crops Research 69: 1-11.

[7] Khush, G. S. (2001) Challenges for meeting the global food and nutrient needs in the new millennium, Proceedings of the Nutrition Society 60, 15-26.

[8] Cakmak I. (2002). Plant nutrition research: Priorities to meet human needs for food in sustainable ways, Plant and Soil 247: 3-24.

[9] Kennedy, G. and Burlinghame, B. (2003). Analysis of food composition data on rice from a plant genetic resources perspective, Food Chemistry 80: 589-596.

[10] Moslehuddin, A. Z. M., Laizoo, S. and Egashira, K. (1997). Fertility status of Bangladesh soils - A review, Journal of the Faculty of Agriculture Kyushu University 41: 257-267.

[11] Neue, H. U., Quijano, C., Senadhira, D. and Setter, T. (1998). Strategies for dealing with micro-nutrient disorders and salinity in lowland rice systems, Field Crops Research, 56: 139-155. 
[12] Savithri, P., Perumal, R. and Nagarajan, R. (1999) Soil and crop management technologies for enhancing rice production under micronutrient constraints, Nutrient Cycling in Agroecosystems 53: 83-92.

[13] Mayer, A-M. B., Latham, M. C., Duxbury, J. M., Frongillo, E.A., Hassan, N. and Biswas, T. (2003). The zinc content of rice in Bangladesh: relationship to soil, production methods, diets and the zinc status of children, FASEB Journal 17: A1200-1200 Part 2 Suppl. S.

[14] Cakmak, I., R. D. Graham, and R. M. Welch. 2002. Agricultural and molecular genetic approaches to improving nutrition and preventing micronutrient malnutrition globally in R. M. Welch and I. Cakmak, eds. Impacts of agriculture on human health and nutrition. Vol. 1. Encyclopedia of Life Support Systems (EOLSS), Developed under the Auspices of the UNESCO. Eolss Publishers, Oxford, U.K. Available at http://www.eolss.net (accessed February 12, 2013).

[15] White, P. J., M. R. Broadley, and P. J. Gregory. (2012). Managing the nutrition of plants and people. App. Env. Soil Sci. 53:2176-2180. Article ID 104826. doi: 10.1155/2012/104826.

[16] Halvin, J. L. and Soltanpour, P. N. (1980). A nitric acid plant tissue digestion method with ICP spectrometry for contaminated soil and plant. Anaytical. Chemistry, 11: 969-980.

[17] Waters, B. M., and R. P. Sankaran. (2011). Moving micronutrients from the soil to the seeds: genes and physiological processes from a biofortification perspective. Plant Sci. 180:562-574. doi: 10.1016/j.plantsci.2010.12.003.

[18] Puig, S., and L. Peñarrubia. (2009). Placing micronutrients in context: transport and distribution in plants. Curr. Opin. Plant Biol. 12: 299-306. doi: 10.1016/j.pbi.2009.04.008.

[19] McLaughlin, M. J., D. R. Parker, and J. M. Clarke. 1999. Metals and micronutrients - food safety issues. Field Crops Res. 60: $143-163$.

[20] Heinemann, R. J. B., P. L. Fagundes, E. A. Pinto, M. V. C. Penteado, and U. M. Lanfer-Marquez. (2005). Comparative study of nutrient composition of commercial brown, parboiled and milled rice from Brazil. J. Food Compos. Anal. 18: 287296. doi: 10.1016/j.jfca.2004.07.005.

[21] Nuss, E. T., and S. A. Tanumihardjo. (2010). Maize: a paramount staple crop in the context of global nutrition. Compr. Rev. Food Sci. Food Saf. 9: 417-436. doi: 10.1111/j.1541-4337.2010.00117.x.

[22] Yang, X.-E., Z.-Q. Ye, C.-H. Shi, and H. Graham. (1998). Genotypic differences in concentration of $\mathrm{Fe}, \mathrm{Mn}, \mathrm{Cu}$, and $\mathrm{Zn}$ in rice grain. J. Plant Nutr. 21:1453-1463.

[23] Gregorio, G. B., D. Senadhira, H. Htut, and R. D. Graham. (2000). Breeding for trace mineral density in rice. Food Nutr. Bull. 21:382-386.

[24] Nube, M. and Voortman, R. L. (2006). Simultaneously addressing micronutrient deficiencies in soils, crops, animals and human nutrition: opportunities for higher yields and better health. Centre for World Food Studies, Amsterdam.

[25] Maziya-Dixon, B., Akinyele, I. O., Oguntona, E. B., Nokoe, S., Sanusi, R. A. and Harris, E. (2004). Nigerian Food Consumption and Nutrition Survey 2001-2003, Summary.
International Institute of Tropical Agriculture (IITA), Ibadan, Nigeria. Retrieved 6 July 2007 from: /http://www.iita.org/cms/details/NFC.pdfS

[26] United States Department of Agriculture, USDA, 2011. Agricultural Research Services, USDA Nutrient Data. Laboratory. 2011. USDA National Nutrient Database for Standard Reference, Release 24.: $\mathrm{http}: / / \mathrm{www}$. ars.usda.gov/nutrientdata.

[27] Jaryum, K. H., Longdet, I. Y., Gazuwa, S. Y. and Clement, E. (2014). Trace Elements Profile of Some Legumes Consumed In Plateau State, Nigeria; International Journal of Biological Sciences, 1:6, 56-65. http://www.dnetrw.com

[28] Jaryum, K. H., Okoye, Z. S. C. and Stoecker, B. (2013). Copper content of staple seeds and grains grown in Kanam local government area, Nigeria; Springer Plus, 2: 373-377. http://www.springerplus.com/content/2/1/373

[29] Kanatti, A., Rai, K. N., Radhika, K. Govindaraj, M., Sahrawat, K. L. and Rao, A. S. (2014). Grain iron and zinc density in pearl millet: combining ability, heterosis and association with grain yield and grain size. Springer Plus 3:763 doi: 10.1186/2193-1801-3-763

[30] Rengel, Z., Batten, G. D., Crowley, D. E. 1999 Agronomic approaches for improving the micronutrient density in edible portions of field crops, Field Crops Research 60: 27-40.

[31] Janusauskaite, Dalia; Arlauskiene, Ausra and Maiksteniene, Stanislava 2013. Soil mineral nitrogen and microbial parameters as influenced by catch crops and straw management Zemdirbyste Agriculture, 100(1): 9-18.

[32] Kitata RB, Chandravanshi BS (2012) Concentration levels of major and trace metals in onion (Allium cepa L.) and irrigation water around Meki Town and Lake Ziway, Ethiopia. Bull Chem Soc Ethiop 26: 27-42

[33] Marschner, H. (1995). Mineral Nutrition of Higher Plants, Academic Press, London.

[34] FAO/WHO (2001) Human Vitamin and Mineral Requirements, report of a joint $\mathrm{FAO} / \mathrm{WHO}$ expert consultation.

[35] Food and Nutrition Board, FNB, (2001) of the National Academy of Sciences, Institute of Medicine. Dietary Reference Intakes for Vitamin A, Vitamin K, Arsenic, Boron, Chromium, Copper, Iodine, Iron, Manganese, Molybdenum, Nickel, Silicon, Vanadium, and Zinc. National Academy Press: Washington DC.

[36] Merchant, S. S. (2010). The elements of plant micronutrients. Plant Physiol. 154: 512-515. doi: 10.1104/pp.110.161810.

[37] Sanghvi T VAM, Baker J, Fiedler J. (2007). In: Sanghvi T, Van Ameringen M, Baker J, Fiedler J, editors. Vitamin and mineral deficiencies technical situation analysis: a report for the ten year strategy for the reduction of vitamin and mineral deficiencies. Tokyo: United Nations University Press; p. S157219, especially S159, 160, 188, 189, 214.

[38] Klevay LM. (2011). Is the Western diet adequate in copper? Journal of Trace Elements in Medicine and Biology; 25: 204 212. www.elsevier.de/jtemb

[39] Klevay LM. (2006). Heart failure improvement from a supplement containing copper. Eur Heart J; 27: 117. 